\title{
ENVIRONMENTAL AND CLIMATIC PROXIES FOR THE CAÑADÓN ASFALTO AND NEUQUÉN BASINS (PATAGONIA, ARGENTINA): REVIEW OF MIDDLE TO UPPER JURASSIC CONTINENTAL AND NEAR COASTAL SEQUENCES
}

\author{
WOLFGANG VOLKHEIMER \\ Instituto Argentino de Nivología, Glaciología y Ciencias Ambientales (IANIGLA), CCT-CONICET, 5500 \\ Mendoza, Argentina.volkheim@mendoza-conicet.gob.ar \\ MIRTA E. QUATTROCCHIO \\ Instituto Geológico del Sur (INGEOSUR/CONICET), Universidad Nacional del Sur, San Juan 670, B8000ICN, \\ Bahía Blanca, Buenos Aires, Argentina.mquattro@criba.edu.ar \\ NORA G. CABALERI \\ Instituto de Geocronología y Geología Isotópica (INGEIS), Universidad de Buenos Aires, CONICET, \\ Ciudad Universitaria, C1428EHA Buenos Aires, Argentina.cabaleri@ingeis.uba.ar
}

PAULA L. NARVÁEZ

Instituto Argentino de Nivología, Glaciología y Ciencias Ambientales (IANIGLA), CCT-CONICET, 5500

Mendoza, Argentina.pnarvaez@mendoza-conicet.gob.ar

ULRICH ROSENFELD

Geologisch-Paläontologishes Institut der Universität. Corrensstraße 24, D-48149, Münster, Germany. rosenfe@uni-muenster.de

\section{LAURA SCAFATI \& DANIEL L. MELENDI}

División Paleobotánica, Museo Argentino de Ciencias Naturales "Bernandino Rivadavia”, CONICET, C1405DJR, Buenos Aires, Argentina.lscafati@macn.gov.ar,dlmelendi@macn.gov.ar

\begin{abstract}
In this review, we include several proxies (sedimentology, palynology, invertebrates) from the Cañadón Asfalto and Neuquén basins, to infer the environments and regional climatic context during the Middle to Late Jurassic of Patagonia. In central Patagonia, early in the Middle Jurassic, and associated with a magmatic arc, began the sedimentary filling of Jurassic continental sub-basins in the Cañadón Asfalto Basin. Lacustrine and fluvio-deltaic sediments, bearing a continental Middle Jurassic palynobiota, correspond to the Las Chacritas Member, while the sediments and palynobiota from the Late Jurassic Puesto Almada Member (both in the Cañadón Asfalto Formation) indicate a palustrine wetland subenvironment immersed within an arid macroenvironment. Paleoinvertebrates (conchostracans and sponges) of this formation suggest wet-dry cycles in the water bodies they inhabited. The sedimentological information together with the continental and coastal palynomorph assemblages of the back arc Neuquén Basin, allowed distinguishing a complete regressive-transgressive sequence for the Middle Jurassic Lajas Formation. For the Upper Jurassic in this basin, the thick gypsum and anhydrite deposits of the evaporitic coastal Auquilco Formation correlate with extended deposits of eolian sandstones corresponding to the Botucatú paleodesert, and a saltmarsh environment is inferred from the palynoflora. The palynologic associations from both basins indicate a regional warm climate with seasonal aridity. Climatic conditions would have been drier in the continental interior (Cañadón Asfalto Basin), with strongly seasonally distributed temperatures, and moister in the western coast of the continent (Neuquén Basin), during the marine transgressions.
\end{abstract}

Key words: paleoenvironment, paleoclimate, Jurassic, Cañadón Asfalto Basin, Neuquén Basin, Argentina.

RESUMO - Na presente revisão foram incluídos vários proxies (sedimentologia, palinologia, invertebrados), das bacias de Cañadón Asfalto e Neuquén, para inferir o contexto climático regional e ambiental durante o Jurássico Médio e Superior da Patagônia. Na região central da Patagônia, no início do Jurássico Médio, e associado a um arco magmático, começou o preenchimento sedimentar de sub-bacias continentais jurássicas na bacia Cañadón Asfalto. Os sedimentos flúvio-deitaico e lacustres, tendo uma palinobiota continental do Jurássico Médio correspondente ao Membro Las Chacritas, enquanto os sedimentos e a palinobiota do Jurássico Superior do Membro Puesto Almada (ambos na Formação Cañadón Asfalto) indicam um subambiente palustre úmido imerso em um macroambiente árido. Os paleoinvertebrados (conchostráceos e esponjas) desta formação sugerem ciclos úmidos-secos nos corpos de água por eles habitados. A informação sedimentológica juntamente com 
as assembleias de palinomorfos continentais e costeiros do "back arc" da bacia Neuquén permitiu distinguir uma sequência completa regressiva-transgressiva para o Jurássico Médio da Formação Lajas. Para o Jurássico Superior, os depósitos de anidrita e gesso espessos da Formação Auquilco costeira evaporítica correlacionam-se com depósitos extensos de arenitos eólicos correspondentes ao paleodeserto Botucatu. Um ambiente "saltmarsh" é inferido a partir da palinoflora. As associações palinológicas de ambas as bacias indicam um clima regional quente com aridez sazonal. As condições climáticas teriam sido mais secas no interior continental (bacia Cañadón Asfalto), com temperaturas fortemente distribuídas de forma sazonal, e úmidas na costa ocidental do continente (bacia de Neuquén), durante as transgressões marinhas.

Palavras-chave: paleoambiente, paleoclima, Jurássico, bacia Cañadón Asfalto, bacia Neuquén, Argentina.

\section{INTRODUCTION}

Contrasting with the geocratic Triassic, the Jurassic is a thalassocratic period, is characterized by wide marine transgressions over the continental areas. That is one of the reasons why the knowledge of the Jurassic terrestrial facies, worldwide, is relatively scarce, comparing it with the plenty of studies on the marine Jurassic. In Argentina, the extensive Jurassic lacustrine deposits of the Cañadón Asfalto Basin in the Middle Chubut River area (Figures 1A,C) have attracted the interest of paleobotanists, vertebrate and invertebrate paleontologists, and petroleum geologists, since the middle of the last century (e.g. Feruglio, 1949; Bonetti, 1963; Tasch \& Volkheimer, 1970; Bonaparte, 1979, 1986; Rauhut, 2002, 2006; Escapa et al., 2008). In the Neuquén Basin (Figures 1A,B), the first palynologic studies were those of Menéndez (1968) and Volkheimer (1968) in mid-Jurassic near-coastal environments. Later followed a large number of palynostratigraphic, paleoecologic, and paleoclimatic publications based on Jurassic palynobiotas. A recent paleobiogeographic study of Wilf et al. (2013) mentions the vertebrate and plant records of Patagonia from the Jurassic through the Paleogene. O. Rauhut expressed in Volkheimer et al. (2008b) that a problem in using Jurassic vertebrates as climatic proxies concerns the fact that many groups (mainly dinosaurs) belong to extinct lineages with no close living relatives, and thus, the climatic preferences and necessities remain speculative. In the Cañadón Asfalto Basin, the presence of anurans, turtles, and crocodiles, are indicative of warm climate when also considering other geologic and paleontologic evidences (Volkheimer et al., 2008b).

In this review, we include previous studies on sedimentology, palynology, and invertebrates, carried out in the Cañadón Asfalto and Neuquén basins (central and northwestern Patagonia; Figure 1). The integration of these proxies is used to show the environments and regional climatic context for the Middle to Late Jurassic. We selected these two sedimentary basins considering that there are no other areas in southern South America with Jurassic outcrops presenting such a plenty of sedimentologic and paleontologic information.

\section{GEOLOGIC SETTING}

During the Mesozoic, between the Early Jurassic and the Late Cretaceous (Maastrichtian), and as a consequence of the beginning of the dispersion of Gondwana, marine and continental sedimentary sequences, as well as volcanic deposits, associated to a magmatic arc, developed in the North Patagonian region. The Cañadón Asfalto Basin (Figures 1A,C) is related with the development of extensional basins formed during the Jurassic rifting in central Patagonia. The map of Figure1C shows the Cerro Cóndor, El Portezuelo-Llanquetruz and Fossati sub-basins of the Cañadón Asfalto Basin. These sub-basins were filled during the Jurassic with lacustrine and fluvial sediments. Where the fractures are profound, the mantle is taken in and the corresponding effusion of volcanites is produced, as observed in the depositional centers of Cerro Cóndor and El Portezuelo-Llanquetruz.

The sub-basins of the Cañadón Asfalto Basin represent a similar tectono-sedimentary process. The lacustrine sedimentation prograded to fluvial systems in basins strike-slip type, related to transtensional faults between the Middle Jurassic to the Early Cretaceous (Silva Nieto et al., 2002a, 2007). In this context, each sub-basin represented an individual and isolated basin, in which the evolutionary history is not necessarily contemporaneous through time (Middle Jurassic to Early Cretaceous). Ramalli et al. (2011) mentioned that the accommodation space and sediment supply was controlled by differential subsidence of fault limited crustal blocks, related to extensional to transtensional tectonism (strike slip) and thermal subsidence. According to these authors: "At any moment of the evolution of the unit, the accommodation space $\mathrm{A}$ and the sediment input $\mathrm{S}$ were sufficiently high as to generate the enlargement of a surface under influence of a lacustrine environment, connecting isolated depocenters, with the simultaneous development of carbonatic facies. The increase of the relation $\mathrm{A} / \mathrm{S}$ could be due to a generalized subsidence of the basin, with changes of the hydrological conditions and climatic fluctuations".

The infilling of the basin initiated early in the Middle Jurassic with an important effusive cycle related with the convergence of the western border of the South American Plate. This volcanosedimentary sequence was named Lonco Trapial Formation (Lesta \& Ferello, 1972). The sedimentation continued with important continental lacustrine-fluvio-deltaic deposits, with basaltic intercalations near the base, corresponding to the Cañadón Asfalto Formation, which rests with a discontinuity over the Lonco Trapial Formation (Figure 2). The Cañadón Asfalto Formation is by far the stratigraphic unit with the highest concentration of organic matter in this region and is divided into two members: Las Chacritas and Puesto Almada, lower and upper respectively.

Two radiometric datings have been obtained for the Las Chacritas Member, a K-Ar age of 170.9 $\pm 4.4 \mathrm{Ma}$ (total rock) 

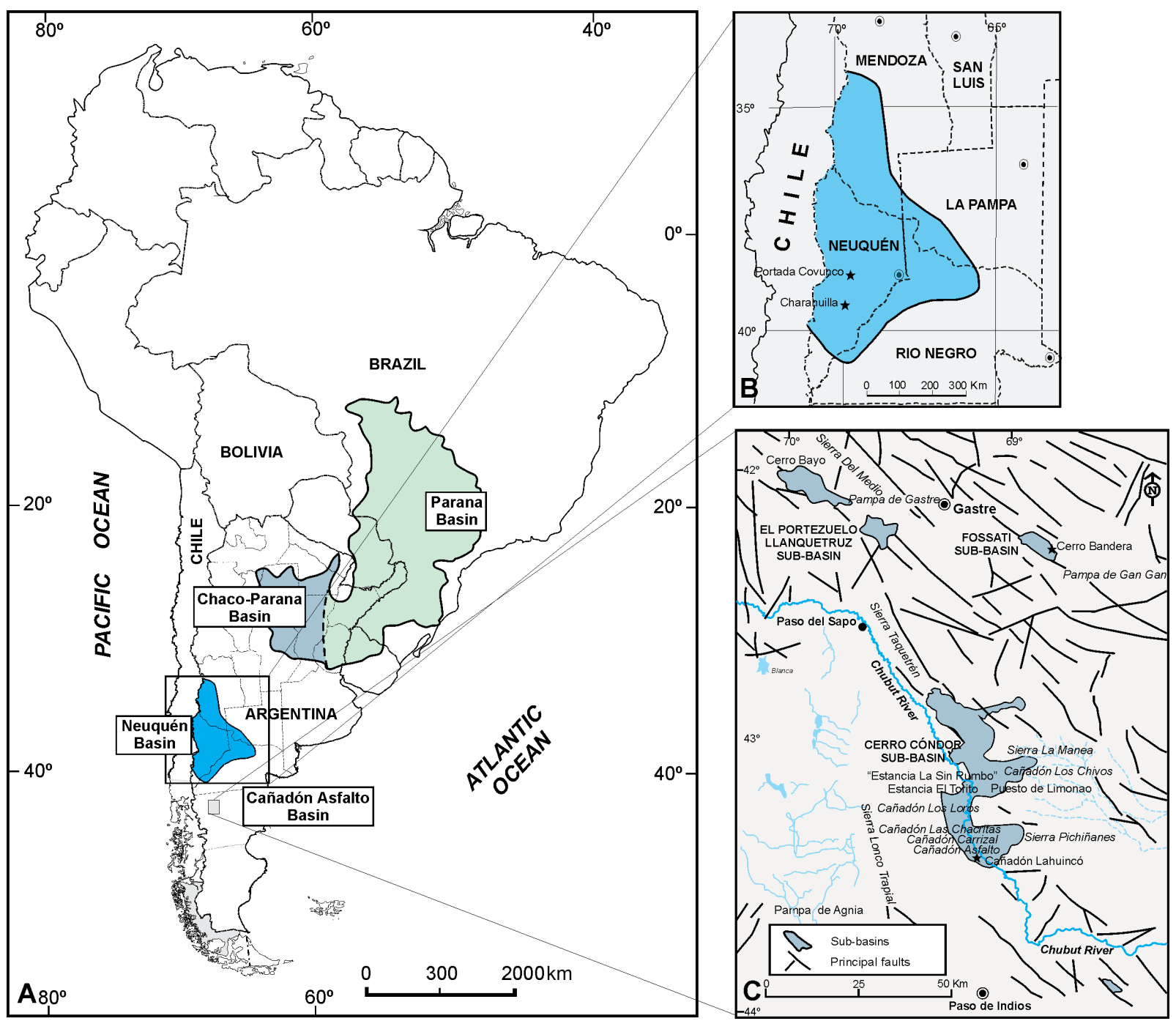

Figure 1. A, location map showing the sedimentary basins mentioned in this paper; B, Neuquén Basin; C, Cañadón Asfalto Basin, sub-basins (El Portezuelo-Llanquetruz, Fossati, and Cerro Cóndor), and main localities. Symbol: stars indicate the localities with palynomorph records considered in this paper.

\begin{tabular}{|c|c|c|c|c|}
\hline E & $\begin{array}{l}\text { Series } \\
\text { Epoch }\end{array}$ & $\begin{array}{l}\text { Stage } \\
\text { Age }\end{array}$ & \multicolumn{2}{|c|}{$\begin{array}{c}\text { CAÑADÓN } \\
\text { ASFALTO BASIN }\end{array}$} \\
\hline \multirow{11}{*}{ 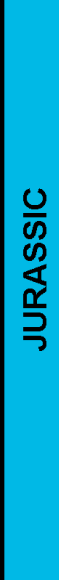 } & \multirow{3}{*}{$\begin{array}{c}\text { Upper } \\
I \\
\text { Late }\end{array}$} & Tithonian & \multirow{3}{*}{$\begin{array}{c}\text { Puesto } \\
\text { Almada } \\
\text { Mb. }\end{array}$} & \multirow{6}{*}{$\begin{array}{l}\text { Cañadón } \\
\text { Asfalto Fm }\end{array}$} \\
\hline & & Kimmeridgian & & \\
\hline & & Oxfordian & & \\
\hline & \multirow{4}{*}{ Middle } & Callovian & \multirow{3}{*}{$\begin{array}{c}\text { Las } \\
\text { Chacritas } \\
\text { Mb. }\end{array}$} & \\
\hline & & Bathonian & & \\
\hline & & Bajocian & & \\
\hline & & Aalenian & \multicolumn{2}{|c|}{ Lonco Trapial Fm. } \\
\hline & \multirow{4}{*}{$\begin{array}{l}\text { Lower } \\
\quad \\
\text { Early }\end{array}$} & Toarcian & \multirow{4}{*}{\multicolumn{2}{|c|}{ Las Leoneras Fm. }} \\
\hline & & Pliensbachian & & \\
\hline & & Sinemurian & & \\
\hline & & Hettangian & & \\
\hline
\end{tabular}

\begin{tabular}{|c|c|c|}
\hline \multicolumn{3}{|c|}{ NEUQUÉN BASIN } \\
\hline Vaca Muerta Fm. & ún Leufú Fm. & \multirow{2}{*}{$\begin{array}{c}\text { Mendoza } \\
\text { Gp. }\end{array}$} \\
\hline \multicolumn{2}{|c|}{ Tordillo Fm. Quebrada del Sapo Fm. } & \\
\hline & \multirow[b]{2}{*}{ Lotena Gp } \\
\hline \multicolumn{2}{|c|}{ Lotena Fm. } & \\
\hline \multirow{3}{*}{\multicolumn{2}{|c|}{ Challacó Fm. }} & \multirow{3}{*}{ Cuyo Gp. } \\
\hline & & \\
\hline & & \\
\hline \multicolumn{3}{|c|}{ Pre-Cuyo Gp. } \\
\hline
\end{tabular}

Figure 2. Stratigraphic chart with the Jurassic units from the Cañadón Asfalto and Neuquén basins. 
indicates an Aalenian-Bajocian age for the basal section at the Cañadón Los Loros locality (Salani, 2007), and a U-Pb Concordia age of $167 \pm 4 \mathrm{Ma}$ (Bathonian) from a tuffite in the lower third outcropping at the Cañadón Asfalto locality (obtained by Natalia Hauser in Cabaleri et al., 2010a). Cúneo et al. (2013) established a Toarcian age (177-176.15 Ma) for the Cañadón Asfalto Formation. Palynostratigraphic analysis also indicated a Middle Jurassic age for the lower section of the Cañadón Asfalto Formation, considering that the form-species integrating the palynobiota of this Formation are also present in the Mid Jurassic Los Molles Formation of the Neuquén Basin (Martínez et al., 2005), and fit well into the latest early Bajocian to early Bathonian Microcachryidites castellanosii Sub-biozone (Martínez, 2002) of the mentioned basin.

For the Puesto Almada Member, Cabaleri et al. (2010a) obtained a U-Pb Concordia age of $161 \pm 3 \mathrm{Ma}$ (CallovianOxfordian limit) at "Estancia La Sin Rumbo" locality, and Koukharsky (in Cabaleri et al., 2010b) reports a Tithonian age of $147.1 \pm 3.3 \mathrm{Ma}(\mathrm{K} / \mathrm{Ar})$ in biotites of tuff levels at the member's type locality (Estancia El Torito), also corroborated by the paleontological evidence of invertebrates: conchostracans and ostracods (Gallego et al., 2011), and vertebrates (Rich et al., 1999; Rauhut et al., 2005).

On the other hand, the Neuquén Basin is located in central western Argentina (Figures 1A,B). It is the southern end of the larger Chilean Basin. The development of this basin began in the latest Triassic. It was an important area of sedimentation during the Jurassic and Early Cretaceous on the eastern side of the evolving Andean mountain chain. Howell et al. (2005) mention that this basin is characterized by three main stages of evolution: initial rift stage; subduction-related thermal sag, and foreland stage. The deposits show the base level changes that occurred both within the basin and along its margins, evidencing the tectonic evolution of the central Andes (Howell et al., 2005). The palynological associations from the Jurassic units of the Neuquén Basin used for comparison in this study correspond to the Lajas and Auquilco formations.

According to Rees et al. (2000), the effects of continental motion can be pronounced and must be considered when interpreting paleoclimates. By the end of the Triassic until the end of the Sinemurian, the Neuquén Basin was at its southernmost position $\left(\mathrm{ca} .50^{\circ} \mathrm{S}\right)$. From then on, it moved northward at about $20 \mathrm{~cm}$ yr-1 and reached its northernmost location $\left(c a .25^{\circ} \mathrm{S}\right)$ in the Pliensbachian. Subsequently, the area moved again to the south at $10 \mathrm{~cm}$ yr- 1 and eventually attained $\left(\mathrm{ca} .30^{\circ} \mathrm{S}\right)$ by the end of the Jurassic, which is similar to its present-day position (Iglesia Llanos et al., 2006).

\section{CAÑADÓN ASFALTO BASIN}

\section{Las Chacritas Member (Middle Jurassic)}

Sedimentology. The Middle Jurassic lacustrine sequence of Extra-andean central Patagonia represented by the Las Chacritas Member outcrops at the Cerro Cóndor (Silva Nieto et al., 2003; Cabaleri et al., 2010b) and Fossati (Cabaleri \& Benavente, 2013) sub-basins of the Cañadón Asfalto Basin (Figures $1 \mathrm{~A}, \mathrm{C}$ ). The lithology of this member consists of limestones, shales, sandstones, and conglomerates intercalated with olivinic basalts, and pyroclastic deposits. The paleoenvironments are defined by littoral lacustrine sequences characterized by mudstones, wackestones, packstones, grainstones, and microbialitic limestones. The wetland environments are better represented in the Cerro Cóndor subbasin by palustrine sequences composed of black shales, black mudstones, incipient paleosoils, and evaporitic evidences.

Different environments related to the paleolakes were recognised in the Cerro Cóndor sub-basin (Figure 1C). In the Cañadón Las Chacritas locality, the facies model corresponds to littoral and marginal environments. The latter are characterized by microbialitic mudstones, with records of storm episodes and dry periods, and formation of evaporitic levels. In the marginal environment, a wide biohermal belt (Figure 3) was developed, in which three growing periods of microbian communities were distinguished. The first corresponds to the biohermal core composed of filamentous green algae. In the second, the stratiform stromatolitic bodies show evidences of subaerial exposition that indicate periods of water body contraction. Finally, the third period is characterized by the development of hemispheric stromatolites affected by desiccation processes (Cabaleri \& Armella, 1999, 2005). The nearshore subenvironment and the facies reflect the expansion and contraction periods of the hydrologically closed basin, in which minor climatic fluctuations are manifested in the physical and chemical water variations (with silica and sulphate precipitation), and in the sedimentological cycles. The depth of the paleolakes was variable and related with the characteristics of the different depositional centers originated in the region (Silva Nieto et al., 2002b; Cabaleri et al., 2006, 2010b). The lacustrine systems were affected by climatic variables, reflected by alternating periods of contraction and expansion of the water bodies (Cabaleri \& Armella, 1999). During the contractions, and as a consequence of the progradation of the coastline, littoral platforms with subaerial exposition developed (Cabaleri et al., 2005). The lacustrine systems received fluvial sediments of different energy levels, related to the tectonic evolution of the basin (Figari \& Courtade, 1993).

Five hundred meters southward of the Cañadón Las Chacritas locality aforementioned, in the Cañadón Carrizal locality, the Las Chacritas Member facies represent shallow lake environments and a saline pan lake (Figure 3). The carbonate-evaporite sequence that crops out is characterized by a shallow lacustrine facies association. This sequence includes an extensive biohermal belt (Figure 3), flood facies of high and low lake-level stages and desiccation-evaporation facies. The basin was defined as a hydrologically closed saline lake.

A detailed sedimentologic study for the Las Chacritas Member in the Fossati depocenter was carried out by Cabaleri $\&$ Benavente (2013). According to the authors, a carbonate paleolake system with ramp shaped margins was associated with wetlands that were eventually affected by subaerial exposure and pedogenesis. Three main subenvironments were distinguished: a lacustrine setting sensu stricto, a palustrine setting, and a pedogenic paleoenvironment. 


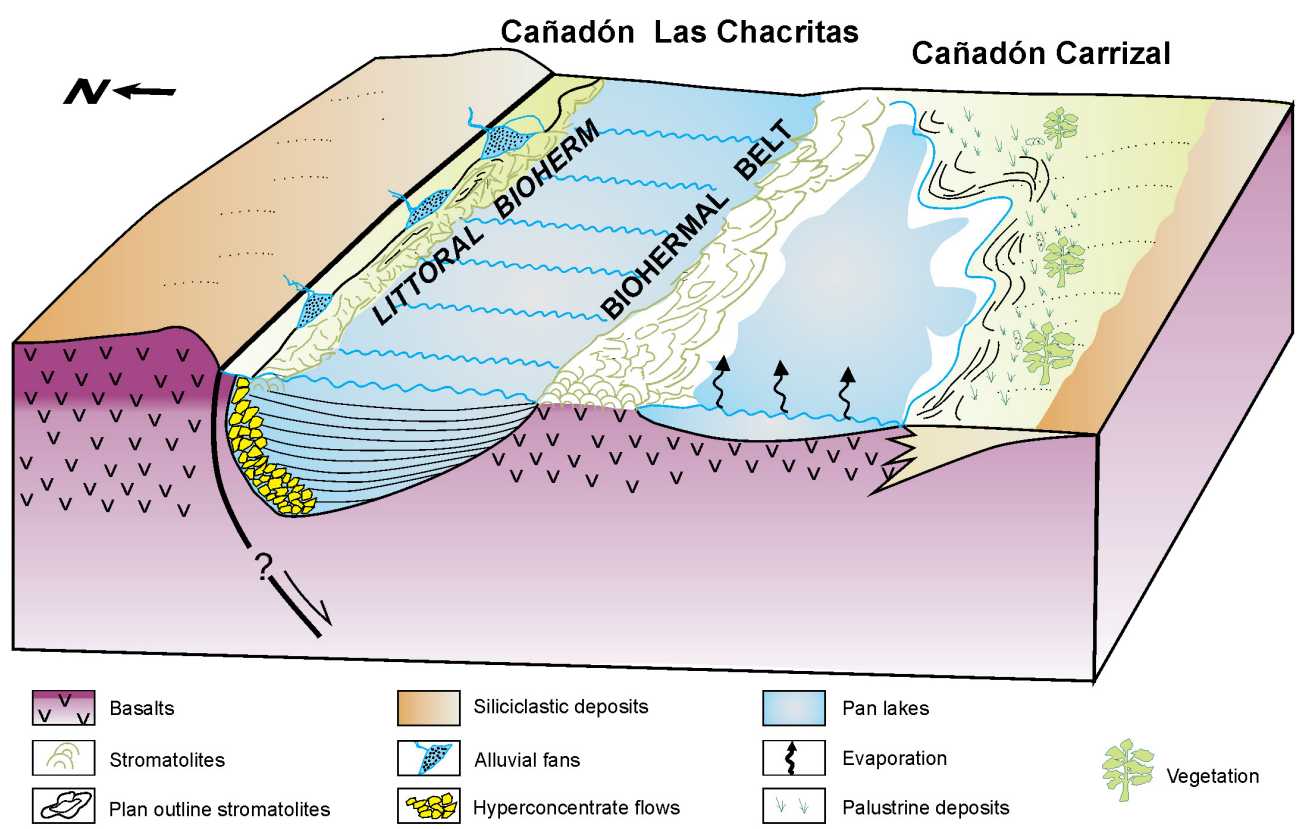

Figure 3. Block diagram showing the environments from the Las Chacritas Member at Cañadón Las Chacritas (lake) and Cañadón Carrizal (palustrine and Pan Lake) localities (modified from Cabaleri et al., 2005).

Isotopes. Environmental isotope analyses were carried out for the Las Chacritas Member from the Cañadón Las Chacritas locality. $\delta^{13} \mathrm{C}$ and $\delta^{18} \mathrm{O}$ values are typical of continental waters. The carbonate facies correspond to a littoral lacustrine environment with recurrent episodes of fluvial water influx. " ${ }^{13} \mathrm{C}$ and $\delta^{18} \mathrm{O}$ values of these carbonates maintain a positive correlation $(r=0.64)$ in agreement with dominantly closed hydrologic conditions" (Ramos et al., 2008). Furthermore, isotopic data of the Cañadón Carrizal locality also indicate a closed basin, pan lake type. Correlation was found between $\delta^{18} \mathrm{O}$ and $\delta^{13} \mathrm{C}$ values and lake-level fluctuations. When pan lake levels are low, any increase in water input causes a large relative increase in lake volume and correspondingly large shifts in the hydrological balance and in the stable isotope signals. Cagnoni et al. (2010) determined that $\delta^{18} \mathrm{O}$ variations are linked to changes in the hydrological balance and $\delta^{13} \mathrm{C}$ variability is linked to modifications in bio-productivity, sometimes adapted to special chemical conditions, due to the extreme salinity of the water.

Palynology. A representative section of the Cañadón Lahuincó locality located in the central part of the Cerro Cóndor subbasin, showing the stratigraphic location of the samples yielding palynomorphs can be observed in Figure 4 of Volkheimer et al. (2008a). High abundance of organic matter in the palynological slides allows inferring stagnant bottom conditions for the lacustrine bodies. The algal assemblage, composed of planktonic (Botryococcus) and non-planktonic (Spirogyra-like spores of the genus Ovoidites) palynomorphs, indicates freshwater conditions. Moreover, the presence of Botryococcus suggests oligotrophic to mesotrophic and euryhaline conditions (Volkheimer et al., 2008a).

High percentages of Classopollis spp. (Figure 4, assemblages A-B), representing the thermophilic Cheirolepidiaceae, an extinct Mesozoic family of conifers, indicate warm climatic conditions and well drained soils around the lakes. Araucariaceae (Callialasporites and Araucariacites) and Podocarpaceae (Podocarpidites and Phrixipollenites) species would have grown in elevated hinterlands. The palynoflora represents a pioneer flora of low diversity growing in the context of a lacustrine basin subject to repeated pyroclastic volcanic activity. A hypothetical section showing the relief and biota at the Cañadón Lahuincó locality is shown in Figure 5. Invertebrates. Tasch (in Tasch \& Volkheimer, 1970) described two new conchostracan species [Cyzicus (Euestheria) volkheimeri and Cyzicus (Lioestheria) patagoniensis] from the Las Chacritas Member, southeast of the Cañadón Lahuincó locality. He also stated that 15 successive seasons were represented in a thickness of $19 \mathrm{~mm}$ of a banded shale: "This points to a seasonal sedimentation rate of $1 \mathrm{~mm}$ or less. Evidence of growth bands of conchostracans point to wet-dry cycles in the water bodies inhabited by the conchostracans" (Tasch \& Volkheimer, 1970).

\section{Puesto Almada Member (Upper Jurassic)}

Sedimentology. The Upper Jurassic unit of the Cañadón Asfalto Basin, the Puesto Almada Member outcrops in the Cerro Cóndor and Fossati sub-basins (Silva Nieto et al., 2003; Cabaleri et al., 2010b; Cabaleri \& Benavente, 2013). It is characterized by limestones (mudstones, bioturbated mudstones, wackestones, packstones, dolostones), shales, sandstones, conglomerates, tuff and tuffaceous deposits, paleosoils (nodular and pisolitic limestones), and rhythmites (limestones and thin pyroclastic laminae). These rhythmites are characteristic from the Puesto Almada Member and are well represented in the outcrops at Estancia El Torito (type locality), Sierra de la Manea, Cañadón de los Chivos, and 


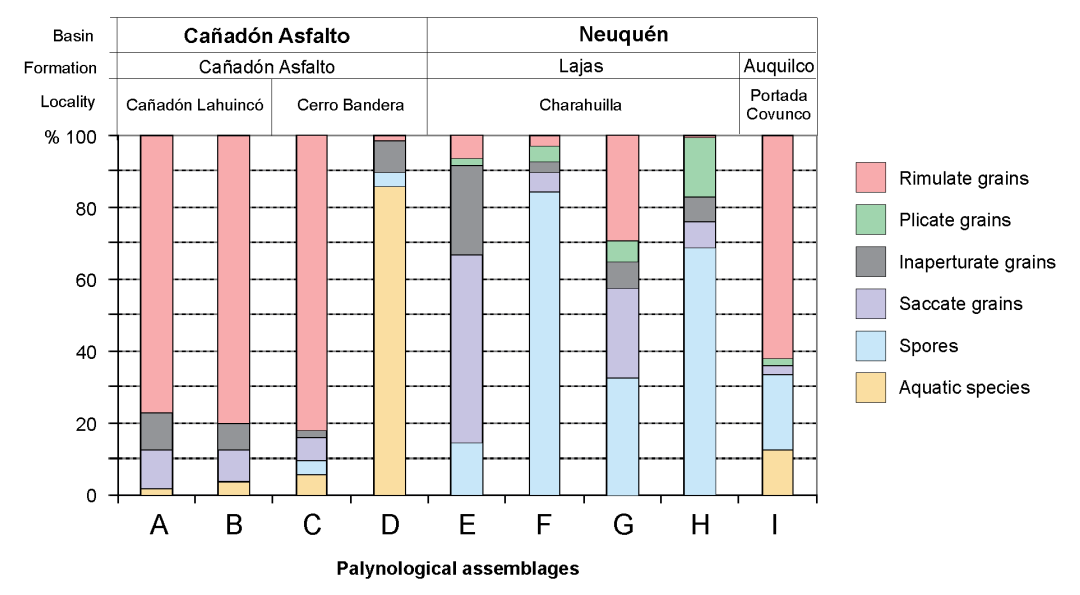

Figure 4. Comparison of the suprageneric groups of palynomorphs from four localities of the Cañadón Asfalto and Neuquén Basins.

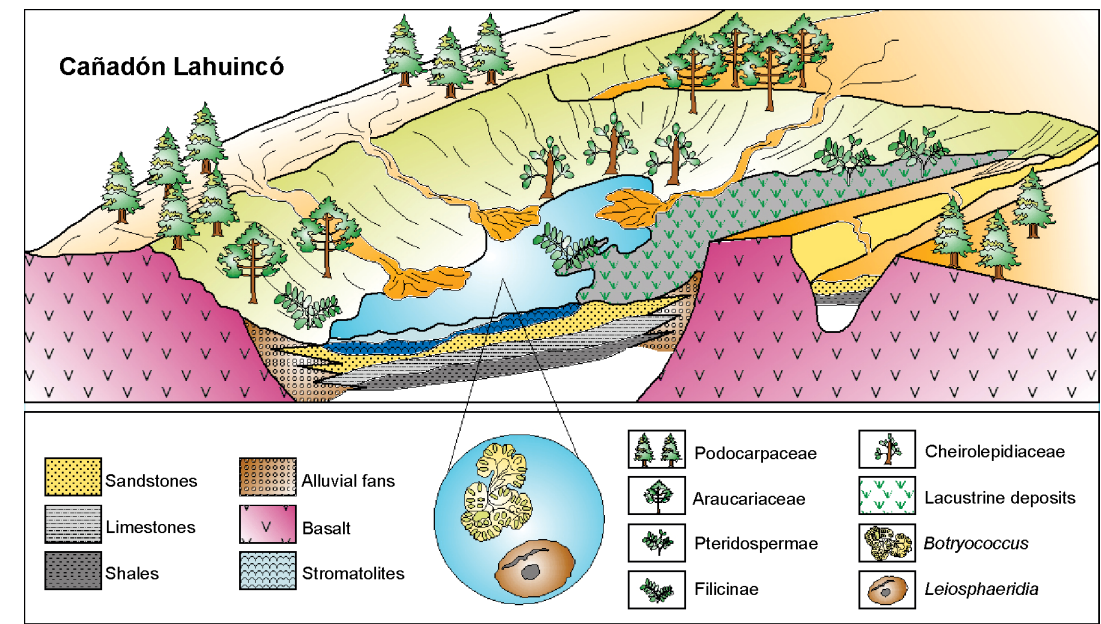

Figure 5. Block diagram showing the environment and vegetation from the Las Chacritas Member at the Cañadón Lahuincó locality (modified from Volkheimer et al., 2008a).

Puesto de Limonao localities (Figure1 C). They are known by their fish content (Coccolepis groeberi Bordas, Tharrias feruglioi Bordas, and Luisiella inexcutata Bocchino) since the publications of Bordas (1942) and Bocchino (1967), and also mentioned in a modern synthesis of López-Arbarello (2004) and López-Arbarello et al. (2013). However, the latter authors consider the fish bearing strata as belonging to the overlying Cañadón Calcáreo Formation and not to the Puesto Almada Member of the Canadón Asfalto Formation as Cabaleri et al. (2010b) proposed.

The Puesto Almada Member in the Fossati sub-basin is represented by siliciclastic and tuffaceous deposits, prevailing fine grained sandstones with horizontal lamination and current ripple marks, middle to coarse grained calcarenites with trough cross stratification, tuffaceous fine to medium grained sandstones and matrix supported conglomerates, with subrounded to rounded clasts of tuffs. The lacustrine paleoenvironments are represented by ponds related to wetland sequences (Figure 6). The ponds are represented by shallow water bodies developed during dry periods, or related with alluvial fan environments (Cabaleri et al., 2010b). The palustrine carbonate facies/microfacies that represent the wetlands are pisolitic, intraclastic and nodular limestones. The sequences are covered by fluvial deposits corresponding to the last synrift stage.

Palynology. Six stratigraphic levels from two wetland deposits of the Puesto Almada Member at the Cerro Bandera locality (Fossati sub-basin; Figure 1C) yielded palynomorph assemblages. The five lowermost levels correspond to the lower wetland environment (Figure 4, assemblage C), characterized by up to $80 \%$ of pollen of Cheirolepidiacean conifers (Classopollis spp.), representing the local flora, together with scarce trilete spores of ferns and bryophytes (Leptolepidites macroverrucosus Schulz, L. verrucatus Couper, and Uvaesporites sp.), occurring in monads and tetrads. These would have grown around small bodies of freshwater were the planktonic coccal green algae (Botryococcus) developed. Nearby elevated areas were inhabited by the gymnosperms Araucariaceae (Araucariacites sp., Callialasporites spp.), Podacarpaceae (Microcachryidites 


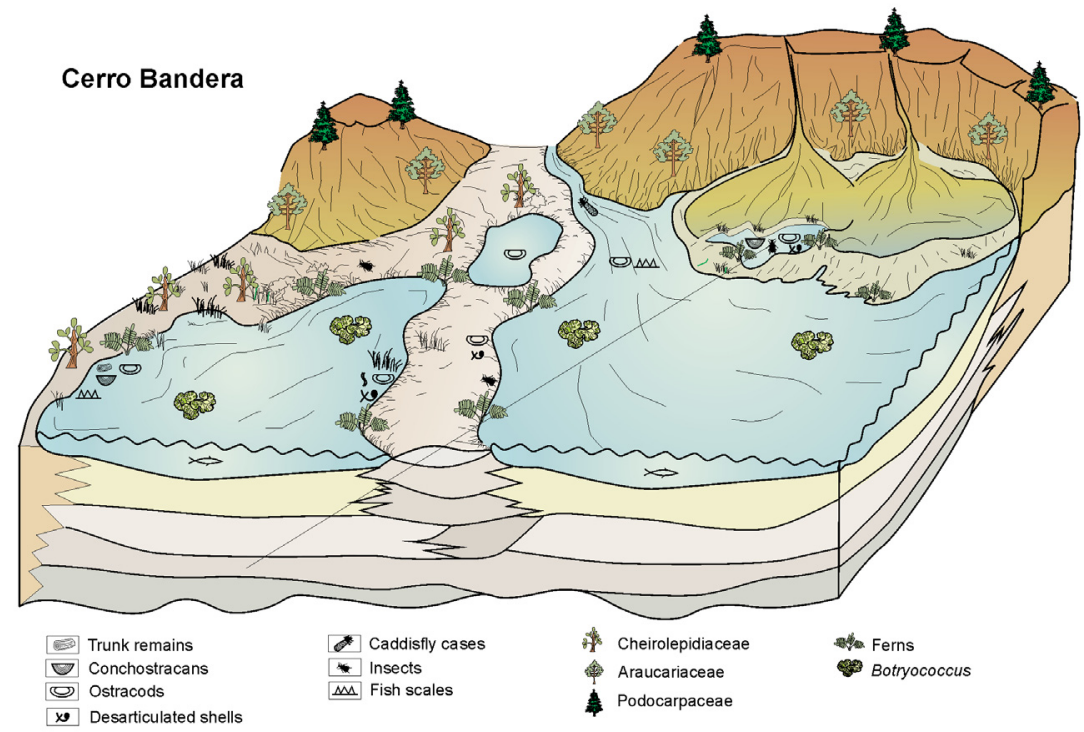

Figure 6. Block diagram showing the environment and vegetation from the Puesto Almada Member at the Cerro Bandera locality.

castellanosii Menéndez, and Podocarpidites sp.), and some pteridosperms (Alisporites sp.). The high representation of Classopollis spp. and the presence of Ephedripites sp., indicate more or less arid environmental conditions and warm to warm-temperate paleoclimate and well-drained soils.

The upper wetland environment is characterized by one level bearing predominantly local aquatic palynomorphs $(86 \%$ of the total assemblage; Figure 4, assemblage D). The high representation of the planktonic green algae Botryococcus sp. indicates a freshwater environment where the benthonic Ovoidites sp. would have also developed. Hygrophile species (Deltoidospora sp. and Gleicheniidites argentinus) would have grown at the borders of the freshwater bodies.

Invertebrates. Completely preserved freshwater sponges (Palaeospongilla chubutensis Ott \& Volkheimer) from the Cerro Cóndor sub-basin allowed paleoecological interpretations (Ott \& Volkheimer, 1972). The sponges form fine layers on thin plant-stems and are covered by thick stromatolitic crusts, formed by cyanobacteria (see Figures 2-4 in Ott \& Volkheimer, 1972). The accompanying fauna (freshwater fish) and the regional context indicate clearly continental (lacustrine) conditions. Volkheimer \& Ott (1973) considered that the sequence yielding the sponges belonged to the Lower Cretaceous Los Adobes Formation of the Chubut Group (overlying the Cañadón Asfalto Formation). However, recent fieldwork studies allowed establishing its correspondence to the Upper Jurassic Puesto Almada Member. On the other hand, Gallego et al. (2010) described Congestheriella rauhuti, the first spinicaudatan from the Puesto Almada Member at the "Estancia La Sin Rumbo" locality. Other invertebrates identified are ostracods, Eosestheriidae conchostracans (adapted to live in arid conditions), bivalve mollusks and gastropods (which occupied shallow ponds), and fossil insects (Order Coleoptera and Hemiptera) related to marginal pond areas near to the river water input (Gallego et al., 2011).

\section{NEUQUÉN BASIN}

\section{Lajas Formation (Middle Jurassic)}

Sedimentology. While the Cañadón Asfalto Basin developed as an extensional basin with continental deposits, the Neuquén Basin was a marine back-arc basin including near coastal deposits. Rosenfeld \& Volkheimer (1979) defined the types of paleoenvironments and the general trend of environmental development within the Lajas Formation at the Charahuilla locality (Sierra de Chacai Có, $55 \mathrm{~km}$ south-southeast of the town of Zapala; Figure 1B). The deltaic deposits are commonly fining-upward sequences that begin with more or less coarse sandstones and grade upwards to sandy-silty and shaly sediments. Mostly the coarse-grained units begin with an erosional contact. Every sequence is characterized by its endmember and belongs to one of the types illustrated in Figure 7:1) incomplete sequence which is cut by the basal sandstone of the following sequence; 2) lacustrine lutites; 3) paleosols; and 4) lignites and carbonaceous shales (Rosenfeld \& Volkheimer, 1979). The coastal sediments may change to brackish or eventually to hypersaline conditions (a possible sequencetype 5). The end-member of this sequence is composed of fine bedded, plant debris bearing silty shales. Occurrence of small pelecypods suggests a brackish environment and the gypsum found in the northern part of the studied area possibly indicates a hypersaline environment.

Palynology. Most Jurassic palynological assemblages from the Neuquén Basin are of marine origin (Martínez, 2002; Martínez \& Quattrocchio, 2004; Martínez et al., 2005, 2008; Quattrocchio et al., 2007). Nevertheless, a Callovian deltaic coal swamp from the Lajas Formation located at the southern Neuquén Basin provided one of the best preserved Jurassic terrestrial palynofloras of Argentina (Charahuilla locality; Figure 1B and Figure 4, assemblages E-H; Volkheimer, 1972). Considering this and other previous palynological and sedimentological records (Rosenfeld 


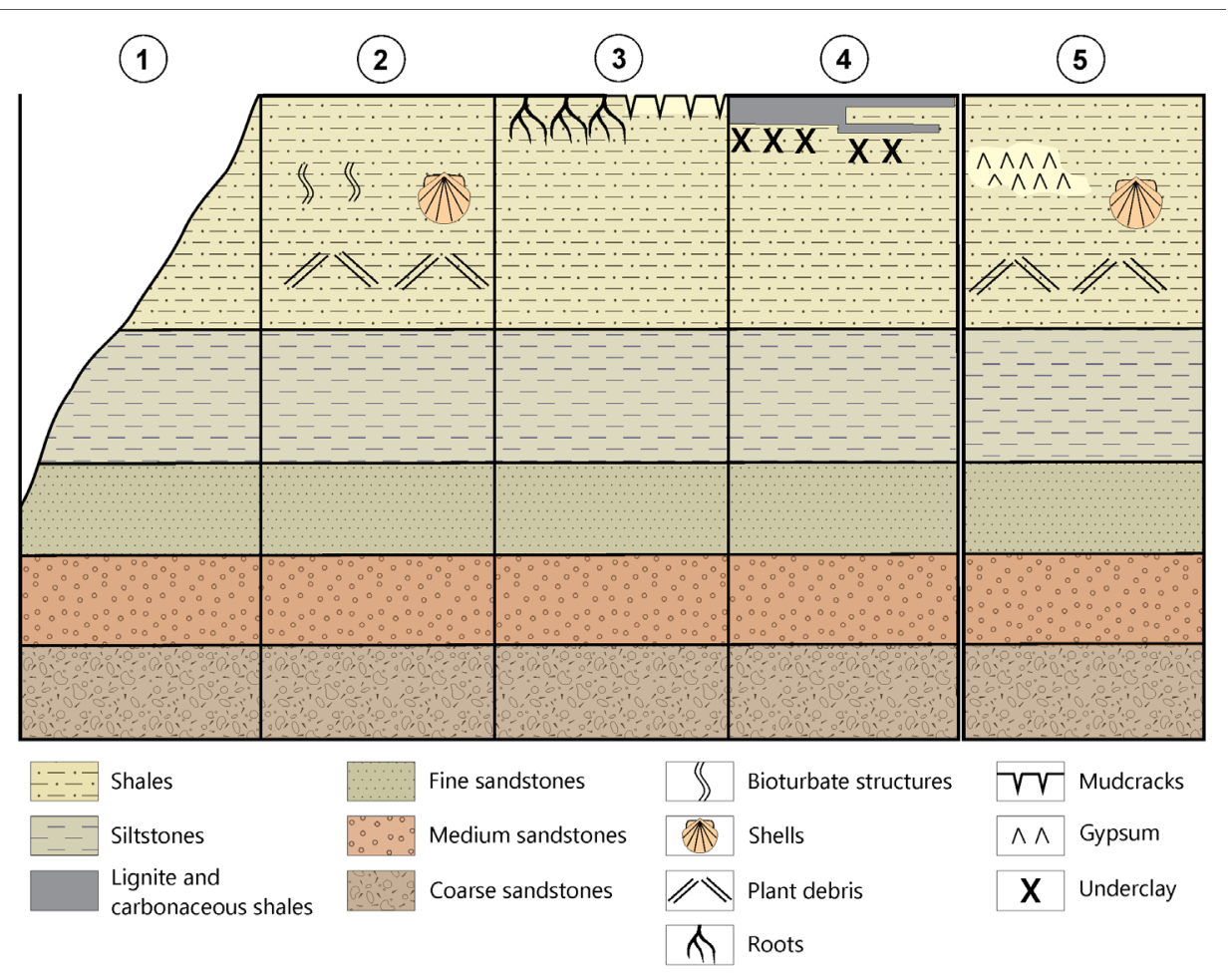

Figure 7. Schematic representation of the types of sequences in the Lajas Formation (modified from Rosenfeld \& Volkheimer, 1979).

\& Volkheimer, 1979; Volkheimer \& Quattrocchio, 1981; González-Amicón \& Volkheimer, 1982; Scafati \& Morbelli, 1984; Martínez et al., 2008), Volkheimer et al. (1984) characterized a complete regressive and transgressive sequence from the Middle Jurassic of the Neuquén Basin, through the statistic study of 19 palynological assemblages, including more than 140 terrestrial and marine species and the sedimentological analysis.

The palynological assemblages from the Lajas Formation represent a series of recurrent environments including: carbonaceous deltaic swamps (Figure 4, assemblages E, H), paleosols (Figure 4, assemblage F), lacustrine (Figure 4, assemblage G), hypersaline, and brackish deposits. Among them, only the latter three contain marine palynomorphs (acritarchs) (Figure 8). The first two environments have high percentages of trilete spores $(84.5 \%$ in the paleosols, and up to $69 \%$ in the deltaic swamps; Figure 4, assemblages $\mathrm{F}$ and $\mathrm{H}$ respectively), indicating local humidity. This contrasts with the regional semiarid macroenvironment inferred by the presence high quantities of Classopollis grains (up to 90\%) associated with bars of the prodelta deposits (García et al., 1994; Volkheimer et al., 2008b). Furthermore, Classopollis is considered as a coastal proxy related to extraordinary flooding of the delta plain, taking into account its dominance and increasing frequencies from the off-shore prodelta deposits to the stream mouth bar (García et al., 1994). These pollen grains would act as a clastic component, sensitive to increments of the sediment input (Volkheimer et al., 2008b).

\section{Auquilco Formation (Upper Jurassic)}

Sedimentology. In the Neuquén Basin, at the southern end of the about $200 \mathrm{~m}$ thick Oxfordian deposits of gypsum (originally anhydrites), a marginal claystone facies outcrops at Portada Covunco locality corrresponding to the Auquilco Formation. Few meters of greenish- gray shales overly the La Manga Formation and are covered by the continental deposits of the Tordillo Formation. The sediments of the Auquilco Formation deposited in a coastal area of an extremely arid region with evaporitic sedimentation near the western coast of Gondwana corresponding to a salt marsh environment (Volkheimer et al., 2008b).

Palynology. The specific richness of the Late Jurassic palynobiota from the Portada Covunco locality is high (58 species; Volkheimer \& Moroni, 1981). The palynological assemblage (Figure 4I) is characterized by the dominance of monoporate pollen grains of the genus Classopollis (Cheirolepidiaceae, 61.5\%). Trilete and monolete spores $(21 \%)$ are frequent and may represent the vegetation consisting of Bryophyta, Lycopodiales and Filicales of coastal swamps, accompanied by Caytoniales (Vitreisporites). Thirteen percent of the species are of marine origin (Leiosphaeridia spp. and cf. Baltisphaeridium) and represent a salt marsh community.

\section{JURASSIC CLIMATE AND PHYTOGEOGRAPHIC PATTERNS}

Compagnucci (2011) mentions that Patagonia was situated mostly within the paleolatitudes influenced by the wind system of the westerlies during the last $250 \mathrm{Ma}$. In her 


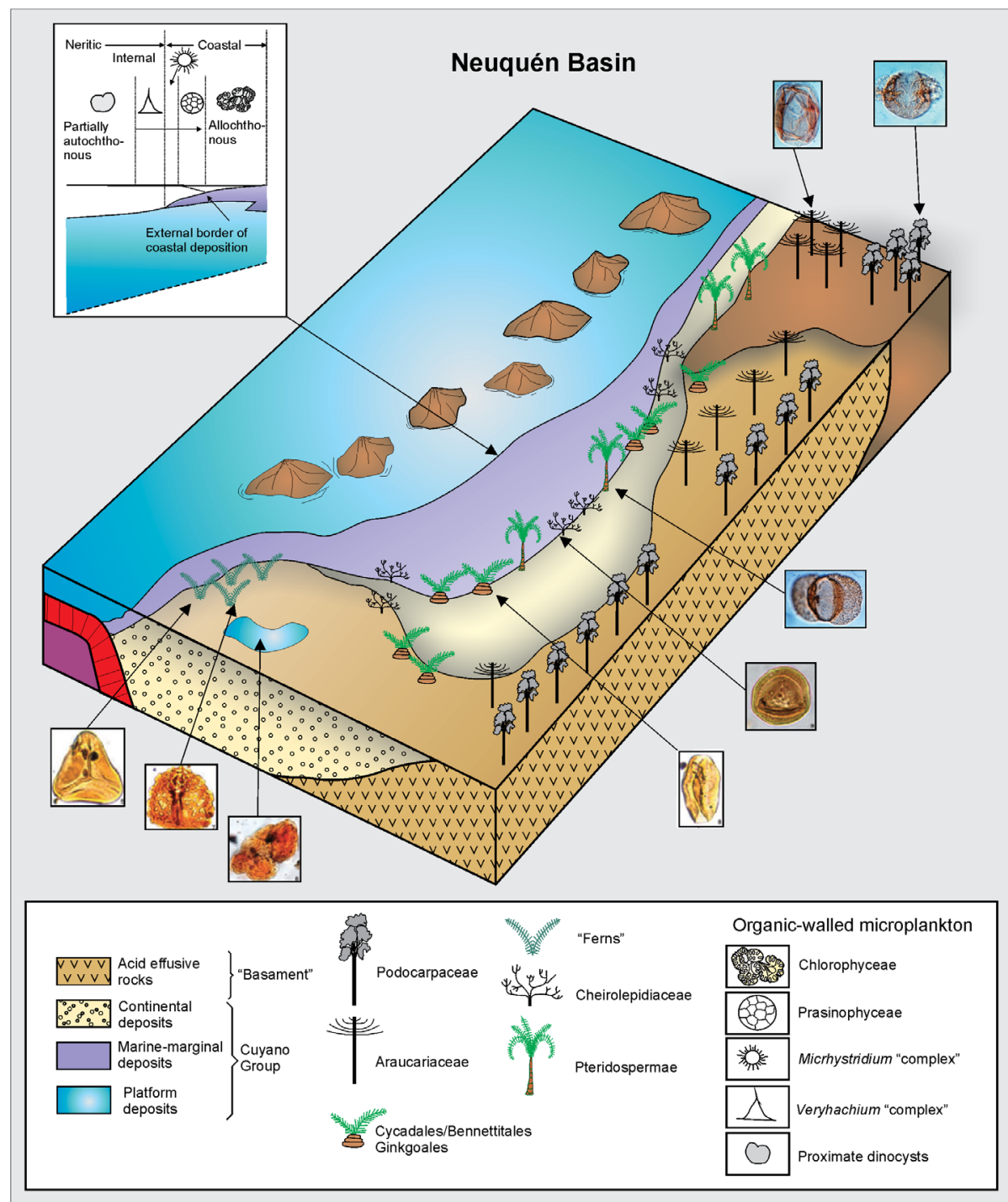

Figure 8. Schematic paleogeography of the Neuquén Basin (modified from Howell et al., 2005) showing the environment and vegetation from the Lajas Formation, Cuyo Group, Neuquén Basin (based on Martínez et al., 2008; Quattrocchio et al., 2011).

own words: "That explains the low frequency of climatic changes. During most of the Mesozoic, the continental mass (as Pangaea was fractured and dismembered) remained far from the poles, thus resulting in large periods of warm climate, without polar ice caps" (Compagnucci, 2011).

For understanding the regional paleoclimatic picture, it is necessary to look northwards and southwards of the area considered in this study. During the Late Jurassic, extremely arid conditions occurred for nearly the whole extension of the Chaco-Paraná and Paraná basins (from Minas Gerais in Brazil, to Uruguay, Paraguay and parts of northeastern and central Argentina) (Figure 1A). The largest paleodesert known so far from the geological record worldwide, the "Botucatúpaleodesert", located between $15^{\circ}$ and $30^{\circ}$ of southern paleolatitude, and had an extension of nearly 2.000 .000 $\mathrm{km}^{2}$. Along the Pacific coast, the extensive Late Jurassic (Oxfordian) deposits of evaporites (anhydrite, gypsum), extending from Zapala (Neuquén Province), through San Juan province in Argentina, to southern Peru. Harrington
(1962) calculated that the total amount of Jurassic anhydrite precipitated in this basin exceeds the total quantity of calcium sulphate in solution in the present oceans.

Towards the south, in the Santa Cruz Province, the Middle to Late Jurassic La Matilde Formation bears stipes of arborescent ferns (Osmundites patagonica), suggesting moist conditions for the plant bearing localities. The silicified woods of the petrified forest of Patagonia (Santa Cruz province) belong to Araucaria (Calder, 1953). Most of them were found in situ and they may represent a subhumid climate with dry seasons. Furthermore, in some levels of the La Matilde Formation, reptile footprints have been described (Casamiquela, 1964), expressing local (or generalized) arid conditions.

Jurassic microfloral similarities indicate close Gondwanic relations between Australia, India, and South America (Quattrocchio et al., 1996; Tiwari, 1999). The Upper Sinemurian-Lower Toarcian (approximately 189.6-180 $\mathrm{Ma}$ ) is characterized by the presence of Classopollis classoides and the absence of the Callialasporites 'complex'. 
Microcachryidites antarcticus is registered since the Lower Bajocian. Significant increase in abundance of $M$. antarcticus and a corresponding decline of the Callialasporites 'complex' (C. dampieri, C. trilobatus, and C. microvelatus) were registered in the Tithonian (150.8-145.5 Ma) (Oppel Zone of Retitriletes watherooensis in Helby et al., 1987; Quattrocchio et al., 1996).

Iglesias et al. (2011) analyzed the Patagonian phytogeographic patterns from a global and evolutionary perspective through geologic times and inferred the biomes contained within the different climatic belts for the southwestern Gondwana on the basis of paleogeographic reconstructions. They mention that the long history of Gondwanic lineages, represented by Araucariaceae, Cupressaceae, and Podocarpaceae, can be traced back to early Mesozoic times. Other groups such as Peltaspermales and Corystospermales that were dominant during the Triassic became extinct by the Jurassic. In general, Jurassic floras are characterized by a low biodiversity and a spatial uniformity, and they constitute five main biomes identified by Rees et al. (2000): Tropical Seasonal Dry (summerwet), Desert, Subtropical Seasonal Dry (winterwet), Warm Temperate, and Cool Temperate. The floras in Argentina and the Antarctic Peninsula are included in the Subtropical Seasonal Dry Biome (see fig. 1C in Iglesias et al., 2011).

\section{FINAL REMARKS}

During the Middle to Late Jurassic, the Cañadón Asfalto and Neuquén basins are mainly characterized by the dominance of the thermophilic pollen genus Classopollis, a common feature with contemporary palynofloras of other parts of the world (Volkheimer \& Pöthe de Baldis, 1976). Classopollis belongs to the Cheirolepidiacean gymnosperms inhabiting semiarid lowlands and coastal areas with well drained soils; they may have formed coastal forests and could have been the main components of a halophytic salt-marsh community (Alvin, 1982). Therefore, the palynological associations of both basins indicate a regional warm climate with seasonal aridity.

Topographically elevated hinterlands with prevailing conifer vegetation (Araucariaceae and/or Podocarpaceae) are characteristic during the Jurassic for both basins. The higher proportions of the trilete spores in the Neuquén Basin imply slightly more humid conditions. Finally, the low specific diversity of the palynoflora of the Cañadón Asfalto Formation could be explained by the high frequency and intensity of the volcanic activity during the deposition.

In the Neuquén Basin, the Late Oxfordian time-slice is especially surprising, due to the large regional extension of lithogenetic climatic proxies, which indicate extreme aridity. The thick gypsum and anhydrite deposits of the evaporitic coastal Auquilco Formation correlate to extended deposits of eolian sandstones on the eastern side of the continent. The eolianites are present between Minas Gerais (Brazil), at the northern end of the Paraná Basin, and the Chaco-Paraná Basin of northeastern and central Argentina. They represent the enormous Botucatu paleodesert and are the record of the largest paleodesert known worldwide in the geological history. Towards the south, in central Patagonia, the sedimentary deposits and the palynological record of the Puesto Almada Member (Cañadón Asfalto Formation) indicate a palustrine wetland subenvironment within the aforementioned arid macroenvironment.

Regarding the information provided by invertebrates, during the Middle Jurassic in central Patagonia, evidence of growth bands on conchostracans from the Las Chacritas Member, point to wet-dry cycles in the water bodies they inhabited (Tasch \& Volkheimer, 1970). These conditions continue through the Late Jurassic (Puesto Almada Member), based on completely preserved freshwater sponges (with gemmules, megascleres, and spiny microscleres; Ott \& Volkheimer, 1972).

The differences between both areas studied could be related with the sheer size of the Gondwana supercontinent configuration (as expressed by Parrish, 1990) and the paleolatitudinal gradient. In general, the continental interior (Cañadón Asfalto Basin) was dry, with strongly seasonally distributed temperatures, while the western coast of the continent, during the marine transgressions in the Neuquén Basin, was moister.

\section{ACKNOWLEDGEMENTS}

This study was supported by the grants: PIP 5222, 5760 and 112-20100100034 of CONICET, Argentina. A. Moschetti carried out the physical and chemical extraction of palynomorphs in the Paleopalynologic Laboratory at IANIGLA. G. Giordanengo (INGEIS-CONICET) collaborated with preparation of digital figures. Thanks to L. Antonioli and M. Arai for the corrections that improved the manuscript. We acknowledge M.J. Garcia for her editorial assistance.

\section{REFERENCES}

Alvin, K.L. 1982. Cheirolepidiaceae: biology, structure and paleoecology. Review of Palaeobotany and Palynology, 37:71-98. doi:10.1016/0034-6667(82)90038-0

Bocchino, A. 1967. Luisiella inexcutata gen. et sp. nov. (Pisces, Clupeiformes, Dussumieriidae) del Jurásico superior de la provincia de Chubut, Argentina. Ameghiniana, 4:91-100.

Bonaparte, J.F. 1979. Dinosaurs: a Jurassic assemblage from Patagonia. Science, 205:1377-1379. doi:10.1126/ science.205.4413.1377

Bonaparte, J.F. 1986. Les dinosaures (carnosaures, allosauridés, sauropodes, cétiosauridés) du Jurassique Moyen de Cerro Cóndor (Chubut, Argentine). Annales de Paléontologie, 72:247-289.

Bonetti, M.A. 1963. Flórula Mesojurásica de la zona de Taquetren (Cañadón del Zaino), Chubut. Revista del Museo Argentino de Ciencias Naturales “Bernardino Rivadavia” e Instituto Nacional de Investigación de las Ciencias Naturales, 1:23-43.

Bordas, A.F. 1942. Peces del Cretáceo del Río Chubut (Patagonia). Physis, 19:313-318.

Cabaleri, N.G. \& Armella, C. 1999. Facies lacustres de la Formación Cañadón Asfalto (Caloviano-Oxfordiano) en la quebrada Las Chacritas, Cerro Cóndor, provincia del Chubut. Revista de la Asociación Geológica Argentina, 54:375-388. 
Cabaleri, N. \& Armella, C. 2005. Estromatolitos lacustres de la Formación Cañadón Asfalto (Caloviano-Kimmeridgiano?), río Chubut Medio provincia del Chubut. Ameghiniana, 42:18R.

Cabaleri, N.; Armella, C. \& Silva Nieto, D.G. 2005. Saline paleolake of the Cañadón Asfalto Formation (Middle-Upper Jurassic), Cerro Cóndor, Chubut province (Patagonia), Argentina. Facies, 51:350-364. doi:10.1007/s10347-004-0042-5

Cabaleri, N.; Armella, C.; Silva Nieto, D. \& Volkheimer, W. 2006. Paleoambientes sedimentarios de la Formación Cañadón Asfalto (Jurásico Superior) en los depocentros de Cerro Cóndor y Gastre - Gan Gan Provincia del Chubut. In: CONGRESO LATINOAMERICANO DE SEDIMENTOLOGÍA, 4, 2006. Resumen, San Carlos de Bariloche, p. 64.

Cabaleri, N. \& Benavente, C.A. 2013. Sedimentology and paleoenvironments of the Las Chacritas carbonate paleolake, Cañadón Asfalto Formation (Jurassic), Patagonia, Argentina. Sedimentary Geology, 284-285:91-105. doi:10.1016/j. sedgeo.2012.11.008

Cabaleri, N.; Volkheimer, W.; Armella, C.; Gallego, O.; Silva Nieto, D.; Páez, M., Cagnoni, M.; Ramos, A.; Panarello, H. \& Koukharsky, M. 2010b. Estratigrafía, análisis de facies y paleoambientes de la Formación Cañadón Asfalto en el depocentro jurásico Cerro Cóndor, provincia del Chubut. Revista de la Asociación Geológica Argentina, 66:349-367.

Cabaleri, N.; Volkheimer, W.; Silva Nieto, D.; Armella, C.; Cagnoni, M.; Hauser, N.; Matteini, M. \& Pimentel, M.M. 2010a. U-Pb ages in zircons from Las Chacritas and Puesto Almada members of the Jurassic Cañadón Asfalto Formation, Chubut province, Argentina. In: SSAGI SOUTH AMERICAN SYMPOSIUM ON ISOTOPE GEOLOGY, 7, 2010. Resumos expandidos, Brasília, p. 190-193.

Cagnoni, M.; Cabaleri, N.G.; Armella, C. \& Panarello, H. 2010. Stable isotope characterization of a saline paleolake of the Cañadón Asfalto Formation (Middle-Upper Jurassic), Cañadón Carrizal, Cerro Cóndor, Chubut province, Argentina. In: SSAGI SOUTH AMERICAN SYMPOSIUM ON ISOTOPE GEOLOGY, 7, 2010. Resumos expandidos, Brasília, p. 338-341.

Calder, M.G. 1953. A coniferous petrified forest in Patagonia. Bulletin British Museum (Natural History), 2:99-138.

Casamiquela, R.M. 1964. Estudios icnológicos. Problemas y métodos de la icnología con aplicación al estudio de pisadas mesozoicas (Reptilia, Mammalia) de la Patagonia. Buenos Aires, Talleres Gráficos Colegio Industrial Pío IX, 229 p.

Compagnucci, R.H. 2011. Atmospheric circulation over Patagonia since the Jurassic to Present: a review through proxy data and climatic modelling scenarios. Biological Journal of the Linnean Society, 103:229-249. doi:10.1111/j.1095-8312.2011.01655.x

Cúneo, R.; Ramezani, J.; Scasso, R.; Pol, D.; Escapa, I.; Zavattieri, A.M. \& Bowring, S.A. 2013. High-precision U-Pb geochronology and a new chronostratigraphy for the Cañadón Asfalto Basin, Chubut, central Patagonia: Implications for terrestrial faunal and floral evolution in Jurassic. Gondwana Research, 24:1267-1275. doi:10.1016/j.gr.2013.01.010

Escapa, I.H.; Sterli, J.; Pol, D. \& Nicoli, L. 2008. Jurassic tetrapods and flora of Cañadón Asfalto Formation in Cerro Cóndor area, Chubut Province. Revista de la Asociación Geológica Argentina, 63:613-624.

Feruglio, E. 1949. Descripción geológica de la Patagonia, Tomo 1. Buenos Aires, Yacimientos Petrolíferos Fiscales, 323 p.

Figari, E.G. \& Courtade, S.F. 1993. Evolución tectosedimentaria de la Cuenca de Cañadón Asfalto, Chubut, Argentina. In: CONGRESO GEOLÓGICO ARGENTINO, 12, 1993. Resumen expandido, Mendoza, p. 66-77.
Gallego, O.F.; Shen, Y.B.; Cabaleri, N.G. \& Hernández, M. 2010. The genus Congestheriella Kobayashi, 1954 (Conchostraca, Afrograptioidea): redescription and new combination to Isaura olsoni Bock from Venezuela and a new species from Argentina (Upper Jurassic). Alavesia, 3:11-24.

Gallego, O.F.; Cabaleri, N.G.; Armella, C.; Volkheimer, W.; Ballent, S.C.; Martínez, S.; Monferran, M.D.; Silva Nieto, D.G. \& Páez, M.A. 2011. Paleontology, sedimentology and paleoenvironment of a new fossiliferous locality of the Jurassic Cañadón Asfalto Formation, Chubut Province, Argentina. Journal of South American Earth Sciences, 31:54-68. doi:10.1016/j. jsames.2010.11.001

García, V.M.; Zavala, C.A. \& Quattrocchio, M.E. 1994. Relación entre análisis palinológico y análisis de facies. Aplicación al Grupo Cuyo (Jurásico Medio) en la Cuenca Neuquina. Revista de la Asociación Geológica Argentina, 49:184-195.

González-Amicón, O.R. \& Volkheimer, W. 1982. Palinología estratigráfica del Jurásico de la Sierra de Chacai Co y adyacencias (Cuenca Neuquina, República Argentina). III: descripciones sistemáticas de los palinomorfos de la Formación Cura Niyeu (Bayociano). Ameghiniana, 19:165-178.

Harrington, H.J. 1962. Paleogeographic development of South America. Bulletin of the American Association of Petroleum Geologists, 46:1773-1814.

Helby, R.; Morgan, R. \& Partridge, A.D. 1987. A palynological zonation of the Australian Mesozoic. Memoirs of the Association of Australasian Palaeontologists, 4:1-94.

Howell, J.A.; Schwarz, E.; Spalletti, L.A. \& Veiga, G.D. 2005. The Neuquén Basin: an overview. In: G.D. Veiga; L.A. Spalletti; J.A. Howell \& E. Schwarz (eds.) The Neuquén Basin, Argentina: a case study in sequence stratigraphy and basin dynamics, London, Geological Society, p.1-14 (Special Publications 252). doi:10.1144/GSL.SP.2005.252.01.01

Iglesia Llanos, M.P.; Riccardi, A.C. \& Singer, S.E. 2006. Palaeomagnetic study of Lower Jurassic marine strata from the Neuquén Basin, Argentina: a new apparent polar wander path for South America. Earth and Planetary Science Letters, 252:379-397. doi:10.1016/j.epsl.2006.10.006

Iglesias, A.; Artabe, A.E. \& Morel, E.M. 2011. The evolution of Patagonian climate and vegetation from the Mesozoic to the present. Biological Journal of the Linnean Society, 103:409-422. doi:10.1111/j.1095-8312.2011.01657.x

Lesta, P. \& Ferello, R. 1972. Región extra andina de Chubut y norte de Santa Cruz. In: A. Leanza (ed.) Geología Regional Argentina, Academia Nacional de Ciencias, p. 601-653.

López-Arbarello, A. 2004. The record of Mesozoic fishes of Gondwana (excluding India and Madagascar). In: G. Arriata \& A. Tintori (eds.) Mesozoic Fishes 3. Systematic, paleoenvironments and biodiversity, Verlag Dr. Friedrich Pfeil, p. 497-624.

López-Arbarello, A.; Sferco, E. \& Rauhut, O.W.M. 2013. A new genus of coccolepidid fishes (Actinopterygii, Chondrostei) from the continental Jurassic of Patagonia. Palaeontologia Electronica, 16:1-23.

Martínez, M.A. 2002. Palynological zonation of the Lajas Formation (Middle Jurassic) of the Neuquén Basin, Argentina. Ameghiniana, 39:221-240.

Martínez, M.A. \& Quattrocchio, M.E. 2004. Palinoestratigrafía y palinofacies de la Formación Lotena, Jurásico Medio de la Cuenca Neuquina, Argentina. Ameghiniana, 41:485-500.

Martínez, M.A.; Quattrocchio, M.E. \& Prámparo, M.B. 2005. Análisis palinológico de la Formación Los Molles, Grupo Cuyo, Jurásico Medio de la Cuenca Neuquina, Argentina. Ameghiniana, 42:67-92. 
Martínez, M.A.; Prámparo, M.B.; Quattrocchio, M.E. \& Zavala, C.A. 2008. Depositional environments and hydrocarbon potential of the Middle Jurasic Los Molles Formation, Neuquén Basin, Argentina: palynofacies and organic geochemical data. Revista Geológica de Chile, 35:279-305.

Menéndez, C.A. 1968. Estudio palinológico del Jurásico Medio de Picún Leufú, Neuquén. Ameghiniana, 5:379-405.

Ott, E. \& Volkheimer, W. 1972. Palaeospongilla chubutensis n. g. et n. sp., ein Süsswasserschwamm aus der Kreide Patagoniens. Neues Jahrbuch für Geologie und Paläontologie, 140:49-63.

Parrish, J.T. 1990. Gondwanan paleogeography and paleoclimatology. In: T.N. Taylor \& E.L. Taylor (eds.) Antarctic paleobiology: its role in the reconstruction of Gondwana, Springer Verlag, p.15-26.

Quattrochio, M.E.; Martínez, M.A. \& Volkheimer, W. 2007. Las floras jurásicas de la Argentina. Asociación Paleontológica Argentina. Ameghiniana, 11:87-100.

Quattrocchio, M.; Sarjeant, W.A.S. \& Volkheimer, W. 1996. Marine and terrestrial Jurassic microfloras of the Neuquén Basin (Argentina); palynology zonation. Georesearch Forum, 1:167-178.

Quattrocchio, M.E.; Volkheimer, W.; Borromei, A.M. \& Martínez, M. 2011. Changes of the palynobiotas in the Mesozoic and Cenozoic of Patagonia: a review. Biological Journal of the Linnean Society, 103:380-396. doi:10.1111/j.1095-8312.2011.01652.x

Ramalli, J.N.; Peroni, G.O.; Boggetti, D.A. \& Manolo, R. 2011. Cuenca Cañadón Asfalto. Modelo tectosedimentario. In: CONGRESO DE EXPLORACIÓN Y DESARROLLO DE HIDROCARBUROS, 8, 2011. Actas, Mar del Plata, p.185-215.

Ramos, A.M.; Cagnoni, M.C.; Cabaleri, N.G.; Armella, C.; Panarello, H.O.; Volkheimer, W. \& Silva Nieto, D.G. 2008. Isotope geochemistry of the lacustrine facies of Cañadón Asfalto Formation at quebrada Las Chacritas, Cerro Cóndor, Chubut. In: SOUTH AMERICAN SYMPOSIUM ON ISOTOPE GEOLOGY, 6, 2008. Proceedings, San Carlos de Bariloche, p. 5.

Rauhut, O.W.M. 2002. Dinosaur evolution in the Jurassic: a South American perspectiva. Journal of Vertebrate Paleontology, 22:89A.

Rauhut, O.W.M. 2006. A brachiosaurid sauropd from the Late Jurassic Cañadón Asfalto Formation of Chubut, Argentina. Fossil Record, 9:226-237. doi:10.1002/mmng.200600010

Rauhut, O.W.M.; Remes, K.; Fechner, R.; Cladera, G. \& Puerta, P. 2005. Discovery of a short-necked sauropod dinosaur from the Late Jurassic periodo of Patagonia. Nature, 435:670-671. doi:10.1038/nature03623

Rees, P.M.; Ziegler, A. \& Valdes, P.J. 2000. Jurassic phytogeography and climates: new data and model comparisons. In: B.T. Huber; H.G. Macleod \& S.L. Wing (eds.) Warm climates in Earth History, Cambridge University Press, p. 297-318.

Rich, T.H.; Rich, P.V.; Giménez, O.; Cúneo, R.; Puerta, P. \& Vacca, R. 1999. A new sauropod dinosaur from Chubut Province, Argentina. National Science Museum Monographs, 15:1-84.

Rosenfeld, U. \& Volkheimer, W. 1979. Types of paleoenvironments of the Middle Jurassic Lajas Formation (Neuquén Basin, Argentina). In: INTERNATIONAL GONDWANA SYMPOSIUM, 4, 1979. Proceedings, Calcuta, India, p. 238-247.

Salani, F.M. 2007. Aporte a la edad de la Formación Cañadón Asfalto, Chubut, Argentina. Amghiniana, 44:65R-66R.

Scafati, L.H. \& Morbelli, M.A. 1984. Nuevos datos palinológicos de la Formación Lajas, Jurásico Medio de la Cuenca Neuquina. In: CONGRESO ARGENTINO DE PALEONTOLOGÍA Y BIOESTRATIGRAFÍA, 3, 1984. Actas, Corrientes, p. 73-105.

Silva Nieto, D.; Cabaleri, N.; Armella, C.; Volkheimer, W. \& Gallego, O. 2007. Hipótesis sobre la evolución tecto-sedimentaria de la Formación Cañadón Asfalto Provincia del Chubut. Ameghiniana, 44:67R.
Silva Nieto, D.; Cabaleri, N. \& Salani, F. 2003. Estratigrafía de la Formación Cañadón Asfalto (Jurásico Superior), provincia del Chubut, Argentina. Ameghiniana, 40:46R.

Silva Nieto, D.; Cabaleri, N.; Salani, F. \& Coluccia, A. 2002a. Cañadón Asfalto, una cuenca de tipo "Pull Apart" en el área de Cerro Cóndor. Provincia del Chubut. In: CONGRESO GEOLÓGICO ARGENTINO, 15, 2002. Actas, Calafate, p. 238-243.

Silva Nieto, D.; Cabaleri, N.; Salani, F.; Márquez, M.; González Díaz, E. \& Coluccia, A. 2002b. Hoja Geológica 4369-27 Cerro Cóndor, Provincia del Chubut. Escala 1:100.000. Buenos Aires, Instituto de Geología y Recursos Minerales, Servicio Geológico Minero Argentino, 68 p. (Boletín 328).

Tasch, P. \& Volkheimer, W. 1970. Jurassic conchostracans from Patagonia. The University of Kansas Paleontological Contributions, 50:1-23.

Tiwari, R.S. 1999. The palynological succession and spatial relationship of the Indian Gondwana Sequence. PINSA, 65:329-375.

Volkheimer, W. 1968. Esporas y granos de polen del Jurásico de Neuquén (República Argentina). 1. Descripciones Sistemáticas. Ameghiniana, 5:333-370.

Volkheimer, W. 1972. Estudio palinológico de un carbón Caloviano de Neuquén y consideraciones sobre los paleoclimas jurásicos de la Argentina. Revista del Museo de La Plata, 6:101-157.

Volkheimer, W. \& Moroni, A.M. 1981. Datos palinológicos de la Formación Auquinco, Jurásico Superior de la Cuenca Neuquina, Argentina. In: CONGRESO GEOLÓGICO ARGENTINO, 8, 1981. Actas, San Luis, p.795-812.

Volkheimer, W. \& Ott, E. 1973. Esponjas de agua dulce del Cretácico de la Patagonia, nuevos datos acerca de su posición sistemática y su importancia paleobiogeográfica y paleoclimatológica. In: CONGRESO GEOLÓGICO ARGENTINO, 5, 1973. Actas, Buenos Aires, p. 455-461.

Volkheimer, W. \& Pöthe de Baldis, D. 1976. Significado estratigráfico de microfloras paleozoicas y mesozoicas de la Argentina y países vecinos. In: CONGRESO IBEROAMERICANO DE GEOLOGÍA ECONÓMICA, 2, 1976. Actas, Buenos Aires, p. 403-424.

Volkheimer, W. \& Quattrocchio, M. 1981. Palinología estratigráfica de la Formación Lotena, Jurásico Medio de la Cuenca Neuquina. In: CONGRESO GEOLÓGICO ARGENTINO, 8, 1981. Actas, San Luis, p.761-775.

Volkheimer, W.; Quattrocchio, M.; Cabaleri, N. \& García, V. 2008a. Palynology and paleoenvironment of the Jurassic lacustrine Cañadón Asfalto Formation at Cañadón Lahuincó, Chubut Province, Central Patagonia, Argentina. Revista Española de Micropaleontología, 40:77-96.

Volkheimer, W.; Scafati, L. \& Rosenfeld, U. 1984. Caracterización palinológica y sedimentológica de una secuencia regresiva y transgresiva en el Jurásico Medio de la Cuenca Neuquina (Argentina). In: CONGRESO LATINOAMERICANO DE PALEONTOLOGÍA, 3, 1984. Memoria, México, p. 165-174.

Volkheimer, W.; Rauhut, O.W.M.; Quattrocchio, M. E. \& Martínez, M.A. 2008b. Jurassic paleoclimates in Argentina, a review. Revista de la Asociación Geológica Argentina, 63:549-556.

Wilf, P.; Cúneo, N.R.; Escapa, I.H.; Pol, D. \& Woodburne, M.O. 2013. Splendid and seldom isolated: the paleobiogeography of Patagonia. Annual Review of Earth and Planetary Sciences, 41:561-603. doi:10.1146/annurev-earth-050212-124217

Received in August, 2013; accepted in December, 2014. 